\title{
Foreign and Domestic Obstacles to Maximum Production
}

\author{
By Edward A. Filene \\ President, William Filene's Sons Company, Boston, Mass.
}

W

ITHOUT industrial stability there cannot be maximum production, and a rapid increase in production to the maximum attainable is what the world needs more than anything else. The more thought the leaders in business, industry and education devote to these matters, the more hopeful I am that a satisfactory solution will be found. I shall try to outline briefly what I regard to be the fundamental principles involved, together with suggestions as to how the obstacles may be overcome.

\section{The European Situation and Max- imum Production in the United States}

In a recently published statement Mr. Hoover is quoted as saying "Words without action are the assassins of idealism." Nothing can be truer as regards the international and domestic problems that confront us. We have talked so much and done so little to help lift Europe out of her slough of despond that $I$ hesitate to add any words of my own to the stupendous amount that has already been spoken and written on the European situation. However, no one can discuss the obstacles to maximum production without touching on conditions abroad, because until Europe returns to normal any program for maximum production represents an ideal that cannot be realized. Steady maximum production in the United States will be found to be impossible unless all the civilized nations are producing nearly normally.

The world war commenced nearly six years ago. For a little more than four years the world suffered the greatest destruction of goods and lives it has ever known. For nearly a year its normal economic life was suspended while the terms of peace were being negotiated and while the great armies were being demobilized. For the past eleven months there has been a nominal peace, but the United States has not shared in it, nor have we helped make it a lasting and enduring peace-a peace that will be the foundation for the maximum production we need.

\section{INTERNATIONAL ECONOMIC AND Industrial Situation}

The post-war world is an entirely different world from the one we knew prior to 1914. Russia, for example, has substituted radical experiments for its former despotic imperial government. As far as the outsider can judge, the change has brought about industrial and economic disorganization that approaches chaos. Although we in America, who are comfortable and well fed, may shudder at and shrink from communism and bolshevism, it cannot be denied that their propaganda have an irresistible appeal to the desperate and the starving. Those who have nothing to lose, not even hope, will embrace the most fantastic schemes in search of food and life. But communism is a menace to maximum production and may sweep Europe, unless Europe's peoples can be fed and clothed and kept profitably employed.

The Germany of the Kaiser is gone, and in its stead is an inexperienced 
republican government. Already the reactionaries have attempted one coup d'etat, which fortunately failed. There is grave danger, though, that other attempts at a counter-revolution will be made. Unless Germany can produce more-not to speak of attaining her maximum production - produceenough to sustain her people and keep them at work, or produce enough to exchange for the food and raw materials she must have to feed her people and keep them at work, it is clear that the present government cannot survive, and it is almost certain that counter-revolution will put the extreme radicals in power. If the extreme left wing of the socialist party or the independents comes into power in Germany, the greatest possible danger to maximum production and the peace of the world may result therefrom.

Austria is a shadow of her former self. Her territory has been divided among the newly formed nations. She has lost practically all of her natural resources and seven-eighths of her population. She is left with Vienna and a small territory unable to support its inhabitants. As a result, conditions in the capital are indescribable. I have had letters from prominent and respected citizens of that city literally begging for assistance in the shape of food drafts or in the shape of employment which would allow a small income in dollars. Nutritive food is almost unprocurable except through the warehouses of the American Relief Administration. The great middle classes and the poor are slowly starving to death. What hope has Austria? What is to keep her from communism and the visionary splendors of that alleged panacea? Austrian money is practically worthless. It is scarcely a medium of exchange. The ordinary machinery of affairs has broken down almost completely. Production, far from being at a maximum, has almost completely ceased.

Poland, Czecho-Slovakia, Jugoslavia - what are they but names on a new map? As governments they are as young and as inexperienced as an infant. They can have no future unless helped and trained and educated as one helps, trains and educates a child. They must trade with one another and with the rest of the world, and yet their financial condition is now such as to preclude extensive trade and to prevent anything approaching maximum production. What would be their fate if Germany and Austria were to unite with Russia? Europe and the world would feel that they must rearm to defend themselves against irrational radicalism. The cost of this rearmament, added to the staggering cost of the war just ended, would increase tax burdens to such an extent that the stability of all governments would be threatened.

What of the Allies? Their condition is, of course, far more hopeful, but they have serious problems nevertheless. All are faced with huge debts, both internal and external; all have inflated currencies; all are suffering from high dollar exchange. Millions of their men have been killed or maimed, and their peoples are war-weary and spiritually worn. They need raw materials, food and machinery from America. Exchange, however, is so unfavorable that purchases are rendered well-nigh impossible. The difficulty of correcting the exchange is enhanced by the fact that the annual interest on Europe's debt to the United States amounts to more than six hundred million dollars. When it is remembered that before the war Europe imported more from the United States than she exported to us, and that any unfavorable balance must be overcome before any impression can be made on the six hundred million 
dollar interest charge, one begins to realize what an enormous development of European industry and trade is necessary before Europe's debt to us can be discharged.

\section{Necessity for Foreign Markets}

Briefly, this is the international situation as $I$ see it, and it is a discouraging one. Every factor that $I$ have pointed out involves the interests of the United States more or less directly. Any catastrophe in Europe will sooner or later be reflected here. We cannot even approach stable maximum production in industry until we are certain first of a stable equilibrium in Europe, and second of a permanent market for our surplus goods; and the second depends on the first. While it is true that for the next year, or possibly two, our own needs are great enough to absorb our own production, and that for this short period the deficits resulting from the war call for increased production in our own country, at the end of that time we must have extensive foreign markets for our goods if our surplus production is not to stagnate on our hands. In my judgment we can have foreign markets only if we assist Europe to readjust herself to normal conditions. The process of readjustment may be slow, but it must be started. The most effective way for starting it is, in my opinion, the ratification of the peace treaty and the participation of the United States in the League of Nations. The many and probably extensive modifications in international relations that may have to be made in working out the terms of the peace treaty can be made satisfactorily only by disinterested international coöperation. It is unthinkable that our great democracy, the greatest proof of the practicability of the democratic ideal, should refuse to take its part and assume its burden with the other nations of the world.

A Nation-Wide Campaign for Sale of Edge Law Corporation SeCURITIES

Fortunately, however, while waiting for ratification of the peace treaty and participation by our country in the League of Nations, we can begin to render assistance. Under the provisions of the Edge Law we can finance the export of necessities to Europe. The formation of Edge Law Corporations, the purchase of their securities by the people of the United States out of their current savings, will go far to counteract the present impossible exchange situation, and to facilitate the resumption of trade and industry abroad on something like a normal basis. I should be glad to see a nation-wide campaign inaugurated for the sale of Edge Law Corporation securities to small investors in every city and hamlet in the United States. Not only would such a campaign yield, in my opinion, huge quantities of money, but it would also be of incalculable value to the people of the United States, as it would stimulate thrift and turn into productive enterprise the millions of dollars that are now being squandered on luxuries and non-essentials.

\section{The United States as World LEADER}

Even we in the United States have our problems, and they are sufficiently difficult to demand the wisest kind of statesmanship in government and in business; but our problems are insignificant when measured against those of Europe. Our debt is relatively small; our taxes, though burdensome, are well within our means. Our country is rich in natural resources, in man power, in initiative and in opportunity. We are equipped as is no other 
country to take a position of unselfish leadership and to mobilize our resources for the service of the world. However, we must put our own house in order, so that our attention need not be distracted by local disturbances.

Recently, I attended the meetings of the Chamber of Commerce of the United States. There was unanimous agreement on the part of business men attending those meetings that the great need of the world was increased production. In the course of the discussion of this subject many reasons were given for the under-production that has followed the war. Mention was made of taxation whereby capital was discouraged in seeking employment in industry and was being invested instead in the exempt securities of states and municipalities; of taxation that encourages huge expenditures for good-will advertising and for other immediately non-productive purposes; of transportation difficulties; of lack of policy with respect to our merchant marine; and of many other things. But the one problem that was mentioned by nearly every speaker was that of industrial relations. Here was the one common obstacle to increased production experienced in all branches of business and industry.

There can be no doubt that the question of industrial relations is one of the most baffling and intricate questions that we have before us.

Industrial Relations Problem an Obstacle to Increased ProDUCTION

\section{The War and Labor Aspiration}

The present phases of industrial unrest that are manifesting themselves throughout the country and that are threatening production are, in my opinion, due to several fundamental causes. In the first place, they are a psychological result of the war-an ex- pression of physical, moral and spiritual restlessness. During the war we were all striving to the best of our ability for one thing - victory. Now that victory has been achieved, we have no such compelling and unifying purpose. The old motive power is gone and we have found no substitute. In the second place, they are the expression of aspiration on the part of labor. The aspiration has always been present, but it is only now that it has been able to find effective expression. Labor, having more nearly perfected its organization, having experienced the advantages of democracy in government, now seeks democracy in industry. Is this unreasonable? Is it any stranger that a man should have a voice as to the conditions under which he works than that he should participate in the management of the city and the state and the nation? If a voter on governmental problems, why not a voter on industrial problems? These are fundamental questions, and on our answer to them depends our economic stability and health.

\section{Americanization}

The problem of what is called "Americanization" is an important factor in this condition. There has been little or no immigration for five years. If this stoppage of our supply of cheap foreign labor should continue for the next twenty-five or thirty years, we should automatically have Americanized our population. The foreign-born element would have been practically eliminated and its children would all be Americans. There is, of course, danger that labor might in this way gain too much power before it was ready to assume so heavy a responsibility, for it would practically control the industrial situation. However, if this danger could be eliminated by developing a new form of industrial 
organization which admitted labor to partnership, it might be expected that one of the greatest obstacles to future maximum production would have been overcome in advance, and that a thoroughly Americanized America would reach new high levels of production.

\section{Employee Representation}

The principle of employee representation is gaining in favor. England has proceeded quite far along these lines. I have recently had a letter from an Englishman, the manager of one of the largest stores in the world, reading in part as follows:

The unrest which characterizes the labour movement all over the world is not merely a question of wages. We have to recognize that we are entering upon a new industrial era. The old links with the past have disappeared, and will never be renewed. The old relations of labour and of capital are happily a thing of the past. The aspirations of the men now are clearly stated to be not only a recognition of their movement as in America, but here a direct participation in the management of the great industries which they have done so much to build up and to maintain.

Our Government I think is to be congratulated on the frank admission of this principle, and in the new Transport Board which has just been formed, which controls the whole of the railways, waterways and highways of this country, four labour representatives will sit with the managers of the other great interests, and discuss not only conditions of labour as it affects their various Unions, but the general administration of this huge organization.

I am convinced that the example set by the Government is one that must be largely followed if we are to secure industrial peace and all those things that flow from it. Happily this principle is being very widely recognized, and Whitley Councils have been established by the hundreds all over the industrial areas of this country.

Strange enough the Retail Merchants lag behind instead of being in the van of this movement helping to educate and direct it. The Retail Distributors of London refused as a body even to recognize the Shop Assistants Union. Already two of the big stores of London-the Civil Service and Army \& Navy-have been compelled to do so by their employees, and I venture to say that in twelve months this principle will have to be admitted by all other organizations as well.

I am strongly of opinion that unless a more liberal attitude, not as regards money, but as regards status, is conceded by the American employers, to the workmen, conditions will not improve, but on the contrary will be a constant source of danger.

We are moving in a more liberal direction here in America, but we are moving slowly. The report of the President's Industrial Conference urged the recognition of the principle of employee representation. In many large industries this principle is now being tried. For years we have had a successful system of this kind in operation in our store in Boston, and I believe firmly in it, not as a concession to the employees, but as a right as inalienable to the right to vote. In our case experience has proved that the recognition of this right has resulted in happier, more efficient, and more reasonable workers. Adequate employee representation will will go far to make strikes and lockouts impossible, to stabilize industry, and to secure maximum production. In addition it will add to the self-respect and sense of individual responsibility of the working man; it will give him a stake in the business that employs him and will decrease labor turnover.

\section{Counterfeit Wages}

The question of wages is closely related to the labor problem. Wages, though higher than ever before, have decreased in purchasing power, and the discrepancy between income and necessary outgo seems to be no less now than it was before the war. There should be a margin of income over outgo if labor is to render its most efficient service. We employers are, for the most part, unconsciously paying to our employees what I call "counterfeit wages;" That is, wages that are not buying a suffciency of food, clothing, shelter and recreation, and that do not permit 
adequate provision to be made for sickness and old age. It is not a question of "how much wages," but "what wages will buy." Wages may have doubled, but if prices have more than doubled the wage earner is worse off than before the change. Employees who find that the dollar in their pay envelopes will not buy a real dollar's worth of goods when taken out, and who worry because they cannot purchase life's necessities for their families, are not efficient employees. It.is to the interest of business men to see to it that the dollars they are putting into the pay envelopes will purchase real dollars' worth of commodities when taken out. Counterfeit wages are as dangerous as counterfeit money.

These, then, are the two fundamental causes of industrial unrest - the aspiration for self-expression through representation in the control of conditions of work and in management, and the demand for real and not counterfeit wages.

Most of our troubles spring from these sources, and we cannot secure maximum production until we have adjusted these difficulties. Capital will be reluctant to engage in industries constantly paralyzed by strikes. If it does so it will charge the "fire-risk" heavily to the consumer. Without capital we cannot hope to increase our production. Capital will be equally reluctant to engage in any industry which depends for its existence upon railroads, coal and shipping (and what industry does not depend on these essentials?) if railroad systems can be tied up, if coal mines can be shut down, and if shipping can be disorganized by strikes.

\section{Public Opinion and Industrial HARMONY}

There is another element in the problem, and that is the element of public opinion. The public is realizing as never before that it has a stake in industrial harmony. Its suffering is no less than that of labor or that of capital when industry is paralyzed by labor trouble. More and more it will take the position that nothing can justify the cessation of service on railroads, in coal mines and in government activities. It will insist that disagreements be arbitrated, and that it be given a voice in the arbitration proceedings. If it decides that minimum wages should be established in these vital activities, it might well be that these minima be fixed at higher levels than in industries where the strike was not frowned on as a means for adjusting compensation.

These are some of the obstacles in the way of maximum production, and some of the means by which these obstacles may be attacked. It seems to me that we must first prepare the way for the new social order by perfecting a method for international cooperation which shall assure to us a sound basis upon which to build the new economic structure. At the same time we must perfect a method for securing coöperation at home between capital and labor and the public, so as to minimize friction and guarantee, so far as possible, that each factor in the complex industrial machinery of the twentieth century will do its part with a view not only to securing its own selfish aims, but also promoting the welfare of the other factors. We no longer have the compelling and unifying purpose of the war. We must seek some other spiritual and moral impulse to bind us together for the common good. It may be that a great religious revival would do this. It seems certain to me that if society, as now organized, is to persist, there must be increased recognition on the part of the world that the basic principles of relig- 
ion-justice, brotherhood and mercyare, in fact, practical rules for the guidance of life, and that the application of these rules to our daily business is the chief guaranty for stable maximum production. We are at the dawn of an epoch in our economic development no less far-reaching in its consequences than has been the past epoch of capitalistic organization, and upon the vision and the justice and the brotherhood of mankind depends not only the maximum production in material things, but also the maximum ethical and spiritual development of the world. 